DOI: 10.46340/eppd.2020.7.6.31

\author{
Olena Shchurko, PhD in Political Science \\ ORCID ID: https://orcid.org/0000-0002-7179-7964 \\ Hetman Petro Sahaidachnyi National Army Academy, Ukraine
}

\title{
MYTH AS A TOOL OF TRANSFORMATION \\ OF PUBLIC CONSCIOUSNESS \\ IN THE MODERN WORLD
}

\author{
Олена Щурко, к. політ. н. \\ МІФ ЯК ІНСТРУМЕНТ ТРАНСФОРМАЦІї \\ СУСПІЛЬНОЇ СВІДОМОСТІ \\ У СУЧАСНОМУ СВIТI
}

Національна академія сухопутних військ імені гетьмана Петра Сагайдачного, Україна

\begin{abstract}
Impact on public consciousness is an effective method of conducting modern hybrid wars. Manipulation of the public opinion becomes a tool for projective states' information attacks on the narratives of the enemy. The suggestive power of constructs is able to substitute social reality with surrogates, to distort historical facts or events, to destructively influence the national idea. Myth as a phenomenon contained in the collective subconscious has unique features that allow its use for external influences. The destruction of national myths and their infliction of destructive hostile, artificially created stereotypes pose a threat to the national identity and information security of the state as a whole. Closed type countries are able to counter such threats through a system of total restriction of access to information, creation of an aggressive ideology, as well as powerful states are able to counter such threats through active support of national consciousness constants, system of national-patriotic education or construction of counter-myths.
\end{abstract}

Keywords: myth, social consciousness, national idea, manipulation, public opinion, narrative.

Постановка проблеми. У XXI столітті усі світові події, явища та загрози набувають глобального характеру внаслідок гіперрозвитку сучасних технологій передачі інформації. Ноосфера переповнення повідомленнями та знаннями, які складно верифікувати та обробити, цифрові мережі витворюють віртуальний світ, який існує паралельно з реальним, а, інколи і підміняє його, що складає проблему самоідентифікації для індивідів, окремих груп та цілих суспільств. Держави творять образи «себе», які наділяють характеристиками та іміджами, актуальними в даний конкретний історичний момент, що здатні гарантувати суспільно-політичну стабільність всередині держави, могутність та проективність в глобалізованому середовищі, забезпечувати національну безпеку i володіють потенцією до трансформацій в стратегічній перспективі. Незважаючи на сучасний прогрес, новітні винаходи, зростання рівня освіченості, функціонування суспільства в епоху трансмодернізму, дискурс якого зосереджений на проблемі самосвідомість («Я») та спільність («Ми») без протиставлення «Іншому» ${ }^{1}$ актуальними та надзвичайно дієвими залишаються технології, що використовують у PR-кампаніях інструменти впливу на трансцендентальні, когнітивні категорії людської свідомості. Методи соціальної психології використовуються не лише для дослідження суспільної думки, чинників, що на неї впливають, а, й більшою мірою, для маніпулятивних впливів, екстраполяції заданих, заздалегідь запрограмованих агентів для зміни когнітивно-поведінкових установок соціуму.

Міф, як найдавніша форма суспільної свідомості, володіє певними ознаками, які визначають його значимість та ефективність в сучасному світі. Виникає парадокс - НТП та НТР надають людству можливості, знання й інформацію, які мали б раціоналізувати уявлення про реальність, пояснювати iii, натомість vis motrix (рушійною силою) соціальних процесів стають міфологічні конструкти, які безпосередньо створює соціум, або, які конструюються суб'єктами для зміни атитюдів.

${ }^{1}$ Mura, A. (2012). The Symbolic Function of Transmodernity. Language and Psychoanalysis. Autumn (1), 67-86. DOI: https://doi.org/10.7565/landp.2012.0005. 
Аналіз останніх досліджень і публікацій. Соціальні функції та особливості трансформації міфу в соціумі досліджували Ж. Бодріяр, Е. Дюркгейм, К. Леві-Строс, первісну міфологію, колективну свідомість, співвідношення міфу і ритуалу філолог Н. Фрай та соціолог Л. Леві-Брюль, вплив міфологічності на свідомість Р. Барт, Ф. Шеллінг наголошував на адаптивності архаїчних міфів та їх існуванні у всі часи, представники антропологічної школи (Е.Тейлор), навпаки, стверджував про лінійність історії та закінчення епохи міфів, формування колективного несвідомого через архетип, як основу міфологічного мислення - К. Юнг, виникнення міфів через психологічні комплекси трактує в контексті психоаналізу 3. Фройд, на індивідуальному рівні (мономіф) ставить в основу творення особистості героя Дж. Кемпбелл, філософські праці Н. Бердяєва, Є. Мелетинського пов'язані із специфікою вивчення міфологічного мислення. В Україні Д. Судин вивчає національні міфи, роль політичного міфу у політичному бутті аналізує Ю. Шайгородський, Г. Почепцов, О. Донченко, Ю. Романенко спеціалізуються на дослідженні політичних міфів та соціальної маніпуляції, формування соціальної психології через міфологізацію розглядають Н. Паніна та Є. Головаха.

Значна кількість наукових праць свідчить про складність та міждисциплінарний характер поняття, мультиваріантність його виявів і трактувань, що обумовлена складністю дослідження наукового феномена міфологізації суспільної свідомості. Наукові розвідки XIX-XX століть розкривали складну структуру архаїчного міфу, наголошуючи на його значимості для формування культурної ідентичності народів та важливості трактування божественної природи влади. У XXI столітті, внаслідок виникнення суспільства знань, науково-технічного прогресу, інформаційно-комунікаційного середовища, модернізації усіх галузей суспільно-політичного існування сучасної цивілізації, залишається проблема розкриття психологічних, соціально значимих аспектів цього феномену свідомості.

Особливої актуальності набуває потреба теоретичного переосмислення та наукової рефлексії поняття міф в умовах сучасних гібридних нелінійних війн та конфліктів, де суспільна свідомість, особливо іï ментально-сутнісні патерни, стають об'єктом деструктивного впливу для зміни когнітивно-поведінкових конструктів ${ }^{1}$.

Виклад основного матеріалу. Міф, як феномен людської свідомості, є міждисциплінарним поняттям, множина його дефініцій зумовлена складністю та полісемантизмом, це - «первинна метамова життя суспільства, яка пояснювала світ і буття», «ідеологічний продукт давніх уявлень про світ», «символічний базис людської культури, що виявляється в мовленнєвій описовій формі... засіб трактування моделей особистої і суспільної поведінки, сутнісних законів соціального й природного космосу», «дійсність, яка приховує той факт, що ії немає» ${ }^{2}$ тощо. Основні характеристики міфу: синкретичність, сугестивність, ірраціональність, символічність, поліморфізм, метафоричність, тривалість в часі, універсальність, амбівалентність, семантична потенційність, тощо, виявляються через його поліфункціональність. Класичні функції міфу (соціально-інтегративна та нормативнорегуляторна, сакральна, мнемонічна, моделююча, пізнавальна) трансформуються та доповнюються для релевантності запитам суспільства (праксеологічна, ідеологічна, комунікативна, мобілізаційна, компенсаторна). У XXI столітті активно використовується множина функцій, але, на нашу думку, саме новітні діяльнісні аспекти цього феномену, сугестивна сила міфу перетворили його на гіперефективний інструмент моделювання когнітивно-поведінкових констант людської свідомості та маніпулювання ними. Через транскордонні потоки інформації та комунікації у глобалізованому світі формується тотальна чи колективна міфологія. Концепція «панміфологізму» поширюється не лише на мистецьку сферу, сучасне суспільство, переживаючи в епоху постмодерну кризу буття, намагається витворювати нові міфологеми для пояснення реальності, яка вже визначається як вторинна стосовно віртуальності (трансмодерн). Науковці прогнозують, що ситуація може ускладнитись у майбутньому - «буде конструюватися реальність» та архетипи «Цифрового» покоління Z» (Google-babies, «Альфа») ${ }^{3}$, генерації «богів, що будуть здатні створювати всесвіти» ${ }^{4}$, жити в віртуальному просторі й вірити в його абсолютність.

\footnotetext{
${ }^{1}$ Скулиш, С. Д. (ред.) (2012). Історія інформачійно-психологічного протиборства. Київ: Наук.-вид. відділ НА СБ України, 212.

2 Бодріяр, Ж. (2004). Симулякри і симуляція. Київ: Основи, 231.

${ }^{3}$ Strauss, W., Howe, N., (1997). The fourth turning: An American prophecy - What the cycles of history tell us about America's next rendezvous with destiny. Broadway Falls, 400.

${ }^{4}$ Terrile, R. (2015). The Universe as a Simulation. <https://www.ideacity.ca/video/richard-terrile-the-universe-as-asimulation/> (2020, листопад, 10).
} 
Продукуються соціальні, політичні, художні, історичні, культурні, релігійні та інші технологічні міфи, які містять синкретичну форму мислення, але не грунтуються на архетипах (К.-Г.Юнг), набувають нових конфігурацій та форм, змодельовані на потребу масової свідомості, коли реальні соціальні чи етичні проблеми замінюють на симулякри, для спрощення сприйняття, або зміщують акценти, викривляючи реальність. Особливу роль у цих процесах впливу та маніпуляції суспільством відіграють політичні міфи, які конструюються з урахуванням усіх особливостей соціальної психології. Політичний міф наділяють властивостями, знаками та символами, які доступними для сприйняття та розуміння, вони спрямовані до примітивних емоційних реакцій та призначені спонукати реципієнта до нераціональних дій. Особливо активними $є$ в період передвиборчих кампаній та під час виборів, виступають частиною боротьби за владу чи доступ до неї. Головне завдання такого продукту PR-технологів та іміджмейкерів створити та підтримувати певні ілюзії в суспільстві, орієнтація на «людину маси»- неосвічену, егоцентричну, яка не визнає авторитетів, що «не вкладаються у їі систему цінностей обумовлених комерційним чи статусним аспектом», здатну мислити за допомогою кліше та стереотипів, відчуває потребу в славі та публічності у власному середовищі, спроможна відмовитись від моралі, тощо, яка буде «споживати міф» як безсумнівну істину.

В процесах пізнання дійсності людина діє відповідно до певних когнітивних установок, які містяться у їі свідомості, вони конструюються з образів реальності (картини світу), що сформована на основі досвіду, архетипів та стереотипів. Відчуття і почуття набувають форми мисленнєвих конструктів, часто неусвідомлюваних, які обумовлюють мотиви, інтереси та поведінку особистості.

Сьогоднішній світ інформаційно переобтяжений, ведеться «он-лайн війна, і он-лайн світ вступає у цю війну» ${ }^{1}$, соціальні мережі стають полем бою. Держави конкурують та змагаються у трьох вимірах: фізичному, інформаційному й віртуальному, захищаючи свою модель світу» ${ }^{2}$, навіть воюють у цих вимірах, але сучасні війни орієнтовані не стільки на фізичне знищення, скільки на «зміну мозку людини...щоб вона бачила світ чужими очима» і самостійно відмовилася від своєї ідентичності. Враховуючи, що «держави - теж люди», в межах теорії соціального конструктивізму, розвиваються в конструйованих умовах реальності, в процесах соціальної взаємодії з іншими акторами міжнародних відносин, є очевидним, що вони також формують і репродукують свою ідентичність, яка впливає на мотиваційні та поведінкові диспозиції ${ }^{3}$ за допомогою міфів. Адже національна ідентичність $\epsilon$ «ключовим елементом суб' єктивної реальності» ${ }^{4}$, «засобом самовизначення й самоорієнтації індивіда у світі крізь призму колективної особистості» ${ }^{5}$, а міфологічний простір, здатний до авторегенерації $\epsilon$ центром, що вберігає культуру від ентропії 6

Суспільства, «як об’єктивна і суб'єктивна реальність одночасно» ${ }^{7}$, здатні конструювати своє минуле на основі вибірковості історичної пам'яті задля задоволення потреб та інтересів, які виникають під впливом конкретної соціально-політичної дійсності чи для того, щоб, інтерпретуючи певним чином історичне минуле, вибудовувати своє майбутнє. Умовно застосовуючи теорію «подорожі героя» Дж. Кемпбелла (вихід - ініціація - повернення), для позначення основних етапів становлення держави, набуття нового досвіду та вдосконалення (модернізації), можна на основі мономіфу, що містить іiі глибинні цінності та ідентифікаційні ознаки створювати концептуальні гранд-наративи, як критично необхідні атрибути держави. Нація створюється через усвідомлення свого «Я» і «Значимого Іншого» (significant one), саме через співставлення з яким і виникає бачення

\footnotetext{
${ }^{1}$ Singer, P., Brooking, E. (2018). LikeWar: the weaponization of social media. New York: Houghton Mifflin Harcourt, 416.

2 Почепцов, Г. (2019). Інтервенції в мізки, або Руйнування здорового глузду. Дзеркало тижня. <https://dt.ua/SOCIUM/intervenciyi-v-mizki-abo-ruynuvannya-zdorovogo-gluzdu-329822>. (2020, листопад, 20).

${ }^{3}$ Wendt, A. (2012). Social Theory of International Politics. Cambridge: Cambridge University Press. 452. DOI: https://doi.org/10.1017/CBO9780511612183.

${ }^{4}$ Berger, P., Luckmann, T., (1966). The Social Construction of Reality: A Treatise in the Sociology of Knowledg. New York: Doubleday \& Company <http://perflensburg.se/Berger\%20social-construction-of-reality.pdf>. (2020, листопад, 25).

${ }^{5}$ Сміт, Е. (1994). Національна ідентичність. Київ: Основи, 224.

${ }^{6}$ Вишницька, Ю. (2013). Міфологічні сценарії в сучасному художньому та публіцистичному дискурсах. Літературознавчі студіi, 39 (1), 185-192.

${ }^{7}$ Berger, P., Luckmann, T., (1966). The Social Construction of Reality: A Treatise in the Sociology of Knowledg. New York: Doubleday \& Company <http://perflensburg.se/Berger\%20social-construction-of-reality.pdf〉. (2020, листопад, 25).
} 
свого образу та образу «Інших», визначаються поняття «Свій», «Інакший» та «Ворог» ${ }^{1}$. Щоб набути рис автентичності будь-яка національна міфологія повинна мати «тенденцію до формування власної космогонії, етіології та есхатології» ${ }^{2}$. Для пояснення чи трактування минулого створюються певні ідентифікаційні орієнтири - сучасні міфи, які покликані «створити» ознаки (образ) народу, які б дозволили ідентифікувати його серед «Інших». Це передовсім історичні міфи про «славне героїчне минуле», міфи про «народних героїв», «про прадавність культури», «про Дух народу». Міфологізація минулого, як частина державної політики, становить підгрунтя для формування національної ідеї та свідомості, виступає консолідуючим чинником для суспільства у складні переломні моменти його існування, зростання загроз національному суверенітету і державі загалом. Міф - своєрідна карта світу та образ реальності, яка міститься в історичній пам'яті народу, якщо оцінкові характеристики спільної історії різняться, або є діаметрально протилежними, то вони обумовлюють несумісні погляди громадян на перспективи держави i нації в майбутньому. Тому сучасні держави активно використовують такий інструмент для підтримання соціальної лояльності, легітимації політичного режиму, творення наративу, що покликаний згуртувати націю в умовах реальних конфліктів чи потенційних загроз з боку проективних агресій ззовні. Міф-як фундаментальний інструмент конструювання наративу, не стільки відображає правду, скільки не «суперечить істині» і створює «ідентичність людини» ${ }^{3}$, як частини «Я» держави.

Загальний характер стрімких суспільних трансформацій, нестабільність структури суспільства, ускладнення соціальних процесів, розмивання кордонів взаємодій, - все це свідчить про те, що ми живемо у «вислизаючому світі» (Е.Гідденс), в епоху «нової невизначеності» (Ю. Хабермас), в кінці знайомого світу» (І. Валлерстайн). Виникає ситуація, коли «гіпертрофована інформація», яку трактують як «надмірну кількість інформації, що вбиває інформацію, надмірну кількість комунікації, що вбиває комунікацію» створює інформаційний вакуум, свідомість наповнюється псевдо знаннями та псевдоінформаціїєю, які здатні на неї деструктивно впливати. Суспільство поринає у світ «змаління сенсів», де навіть передвиборчий процес, як одна із головних демократичних цінностей у розвинених державах, з боротьби ідеологій перетворився на змагання «партійних брендів і осіб політиків, які вже давно з реальних людей перетворилися на телесимулякри» ${ }^{4}$. Політики та політичні партії, маніпулюючи свідомістю людей, забезпечують собі перемогу на виборах через дезінформацію i створюють прецедент, коли такі способи боротьби за владу стають нормою і не викликають заперечення чи спротиву громадянського суспільства чи міжнародного середовища, що становить загрозу сучасним демократіям.

Наприкінці XX століття Й. Масуда стверджував, що «інформаційно-технологічна революція... зробить можливим масове виробництво когнітивної і систематизованої інформації, нових технологій i знань, основою інформаційного суспільства стануть комп'ютерні технології», а володіння інструментами формування образів реальності стало не менш ефективним «засобом тиску, ніж зброя масового знищення» ${ }^{6}$. Проективні держави використовують міфи як інструменти «зламу» суспільної свідомості в умовах посилення транспарентності суспільств та гомогенності світової комунікації.

Висновки. Глобалізація виявляється не лише як процес об'єднання економік та впорядкування світової системи відносин, а й як тривалий процес уніфікації, стандартизації та інтеграції свідомості. Масовість стає ознакою сучасності, цінності та норми транслюються в процесах комунікації, обумовлюючи стирання індивідуальних (національних) «сенсів буття», відчуження смислотворчих релігійних та культурних констант соціуму, підміна істини, правди та знання їх симулякрами набуває тотального характеру. Міф стає інструментом «ідеологічної деформації колективної свідомості» ${ }^{7}$ методом «інтелектуального бриколажу, згідно з яким образна логіка вибудовується манівцями: смисл

\footnotetext{
${ }^{1}$ Snyder, T. (2003). The Reconstruction of Nations. Poland, Ukraine, Lithuania, Belarus, 1569-1999. Yale University Press, 367.

${ }^{2}$ Гриценко, О. (1998). Міфи. Нариси української популярної культури. Київ: УЦКД, 184.

${ }^{3}$ Почепцов, Г. (2019). Інтервенції в мізки, або Руйнування здорового глузду. Дзеркало тижня. <https://dt.ua/SOCIUM/intervenciyi-v-mizki-abo-ruynuvannya-zdorovogo-gluzdu-329822>. (2020, листопад, 20). ${ }^{4}$ Окара, А. (2006). «Консервативна Революція» Юлії Тимошенко: солідаризм як бренд, утопія і технологія. Українська правда. <https://www.pravda.com.ua/rus/articles/2006/03/14/4397780/. (2020, листопад, 20).

${ }^{5}$ Masuda,Y. (1983). The Information Society as Post-Industrial Society. Washington: World Future Society. 178.

${ }^{6}$ Прайс, М. (2000). Телевидение, телекоммуникации в переходный период: право, общество и национальная идентичность. Москва: Изд-во МГУ, 336.

7 Жулинський, М. (2010). Нація. Культура. Література : наџ..-культ. міфи та ідейно-естет. пошуки укр. л-ри. Київ: Наук. думка, 560.
} 
осягається ніби ненароком, всі образи, символи, мотиви, абстракції, предмети ніби розсипаються на частини, щоб потім з'єднатися, переплестися, зчепитися», утворюючи «парасенси» (псевдосенси) існування нації. «Бриколажний метод можливий лише при наявності такої моделі картини світу в якій допустима безліч міфосвітів» ${ }^{1}$. Такі атаки є найбільш деструктивними для суспільної свідомості, образи, що у них сформувалися стають певними константами для сприйняття реальності, можуть ставати базисом наступних «псевдоуявлень чи стереотипів», які здатні проникати в підсвідомість $i$, навіть ставати частиною колективної пам'яті. В потрібний момент ці міфи реанімуються, активізуються і стають тригерами для соціуму, що запускають запрограмовану реакцію (акції протестів, коливання валют на ринку, політичні кризи) для досягнення непередбачуваних катастрофічних результатів для держави.

Міфологізується політичний простір, створюються чи руйнуються іміджі політиків та політичних партій, профануються політичні процеси в інформаційно-комунікативному просторі, створюється паралельна віртуальна реальність, особливо соціальних мережах, популярному F.A.A.N.G. (акронім компаній Facebook, Apple, Amazon, Netflix, Google), які «створюють стандарти майбутнього. I світ не пригальмує в своєму розвитку, щоб ми змогли у ньому зорієнтуватися» ${ }^{2}$. Комерціалізація віртуальності ${ }^{3}$ та здатність до віральності інформації, знань та меседжів, практично унеможливили їх контроль, відслідковування і перетворили на середовище «відмивання» наративів ...їх «переміщення з компетенції держав в широку медіа-екосистему через тиражування потрібних повідомлень (міфів), використання «корисних ідіотів» в інтересах зацікавлених суб'єктів, що обумовлено тактикою активних дій 3 довгою історією» ${ }^{4}$. Причинами активізації міфотворчості та дієвість маніпулятивних технології використання міфів, як інструментів конструювання суспільної свідомості в сучасний час, $є$ : намагання соціуму реалізувати психологічну компенсаторну функцію, активний пошук системи соціальних координат в умовах мінливості мультисвіту, спроба змоделювати ідеальний простір свободи, створити соціальну реальність, раціоналізовану ідеологією консолідації, боротьба індивідуальної та соціальної міфологій ${ }^{5}$, адже впорядковуючи, організовуючи, моделюючи суспільство, міфи можуть ставати конструктивними і деконструктивними чинниками освоєння та раціоналізації дійсності.

\section{References:}

1. Bodriiar, Zh. (2004). Symuliakry i symuliatsiia [Simulacra and simulation]. Kyiv: Osnovy. [in Ukrainian].

2. Vyshnytska, Yu. (2013). Mifolohichni stsenarii v suchasnomu khudozhnomu ta publitsystychnomu dyskursakh [Mythological scenarios in contemporary artistic and journalistic discourses.]. Literaturoznavchi studii [Literary studies], 39 (1), 185-192. [in Ukrainian].

3. Hrytsenko, O. (1998). Mify. Narysy ukrainskoi populiarnoi kultury [Myths. Essays on Ukrainian popular culture]. Kyiv: UTsKD. [in Ukrainian].

4. Zhulynskyi, M. (2010). Natsiia. Kultura. Literatura : nats.-kult. mify ta ideino-estet. poshuky ukr. l-ry [Nation. Culture. Literature: national-cultural myths and ideological-aesthetic searches of Ukrainian literature]. Kyiv: Nauk. dumka. [in Ukrainian].

5. Skulysh, Ye.D. (ed.) (2012). Istoriia informatsiino-psykholohichnoho protyborstva : pidruchnyk [History of information and psychological confrontation]. Kyiv: Nauk.-vyd. viddil NA SB Ukrainy. [in Ukrainian].

6. Okara, A. (2006). «Konservatyvna Revoliutsiia» Yulii Tymoshenko: solidaryzm yak brend, utopiia i tekhnolohiia [Yulia Tymoshenko's Conservative Revolution: Solidarity as a Brand, Utopia and Technology]. Ukrainska pravda [Ukrainian Pravda]. <https://www.pravda.com.ua/rus/articles/2006/03/14/4397780/>. (2020, November, 20). [in Ukrainian].

7. Pocheptsov, H. (2019). Interventsii v mizky, abo Ruinuvannia zdorovoho hluzdu [Interventions in the brain, or the destruction of common sense.]. Dzerkalo tyzhnia [Mirror of the week]. <https://dt.ua/SOCIUM/intervenciyiv-mizki-abo-ruynuvannya-zdorovogo-gluzdu-329822>. (2020, November, 15). [in Ukrainian].

\footnotetext{
${ }^{1}$ Вишницька, Ю. (2013). Міфологічні сценарії в сучасному художньому та публіцистичному дискурсах. Літературознавчі студї, 39 (1), 185-192.

${ }^{2}$ Nordström, K., Ridderstråle, J. (2002). Funky Business: Talent Makes Capital Dance. London: Pearson Education Ltd, 219.

${ }^{3}$ Почепцов, Г. (2019). Феномен двоемыслия: вчера, сегодня, завтра. Дзеркало тижня.

<https://zn.ua/SOCIUM/fenomen-dvoemysliya-vchera-segodnya-zavtra-333754_html l>. (2020, листопад, 23).

${ }^{4}$ Fsi-Live (2019). White Paper "Potemkin Pages and Personas" <https://fsi-live.s3.us-west-1.amazonaws.com/

s3fs-public/potemkin-pages-personas-sio-wp.pdf $>$. (2020, листопад, 11).

${ }^{5}$ Вишницька, Ю. (2013). Міфологічні сценарії в сучасному художньому та публіцистичному дискурсах.

Літературознавчі студї, 39 (1), 185-192.
} 
8. Pocheptsov, H. (2019). Fenomen dvoemyslyia: vchera, sehodnia, zavtra [Doublethink phenomenon: yesterday, today, tomorrow]. Dzerkalo tyzhnia. [Mirror of the week]. <https://zn.ua/SOCIUM/fenomen-dvoemysliya-vcherasegodnya-zavtra-333754_html l>. (2020, November, 23). [in Russian].

9. Prais, M. (2000). Televydenye, telekommunykatsyy v perekhodnyi peryod: pravo, obshchestvo y natsyonalnaia ydentychnost [Television, telecommunications in transitional period: law, society and national identity]. Moscow: Yzd-vo MHU. [in Russian].

10. Smit, E. (1994). Natsionalna identychnist [National identity]. Kyiv: Osnovy. [in Ukrainian].

11. Berger, P., Luckmann, T., (1966). The Social Construction of Reality: A Treatise in the Sociology of Knowledg. New York: Doubleday \& Company. Perflensburg <http://perflensburg.se/Berger\%20social-construction-ofreality.pdf $>$. (2020, November, 25). [in English].

12. Masuda,Y. (1983). The Information Society as Post-Industrial Society. Washington: World Future Society. [in English].

13. Mura, A. (2012). The Symbolic Function of Transmodernity. Language and Psychoanalysis, Autumn (1), 67-86. DOI: https://doi.org/10.7565/landp.2012.0005. [in English].

14. Nordström, K., Ridderstråle, J. (2002). Funky Business: Talent Makes Capital Dance. London: Pearson Education Ltd. [in English].

15. Singer, P., Brooking, E. (2018). LikeWar: the weaponization of social media. New York: Houghton Mifflin Harcourt. [in English].

16. Snyder, T. (2003). The Reconstruction of Nations. Poland, Ukraine, Lithuania, Belarus, 1569-1999. Yale University Press. [in English].

17. Strauss, W., Howe, N., (1997). The fourth turning: An American prophecy - What the cycles of history tell us about America's next rendezvous with destiny. Broadway Falls. [in English].

18. Terrile, R. (2015). The Universe as a Simulation. <https://www.ideacity.ca/video/richard-terrile-the-universeas-a-simulation/>. (2020, November, 10). [in English].

19. Wendt, A. (2012). Social Theory of International Politics. Cambridge: Cambridge University Press. DOI: https://doi.org/10.1017/CBO9780511612183. [in English].

20. Fsi-Live (2019). White Paper "Potemkin Pages and Personas" <https://fsi-live.s3.us-west-1.amazonaws.com/ s3fs-public/potemkin-pages-personas-sio-wp.pdf>. (2020, November, 11). [in English]. 